\title{
Essential oil composition of wild growing Sage from R. Macedonia
}

\author{
Gjoshe Stefkov, Ivana Cvetkovikj*, Marija Karapandzova, Svetlana Kulevanova \\ Institute of Pharmacognosy, Faculty of Pharmacy, University "Ss. Cyril and Methodius" - Skopje, R. Macedonia
}

Received: February 2012; Accepted: March 2012

\begin{abstract}
The main objective of this study was to analyze and identify the essential oil composition of S. officinalis populations growing in Republic of Macedonia and to evaluate these data according to different standards' requirements for, commercially most utilized, Dalmatian sage. The essential oil yield, obtained after hydrodestilation from leaves, of three different populations of Salvia officinalis L. from Republic of Macedonia was determined, varying from 1.40 to 3.46\%. The GC/FID/MS analysis of the composition of the essential oils revealed 63, 57 and 51 components in Galicica Mtn., Jablanica Mtn. and Karaorman Mtn. sage populations, respectively. The main components of the oil, in all three samples, were the terpene hydrocarbons, encompassing the monoterpenes: camphor (13.15 - 25.91\%), $\alpha$-thujone $(19.25-26.33 \%)$, $\beta$-thujone $(2.03-5.28 \%), 1,8$-cineole $(6.51-13.60 \%)$, $\alpha$-pinene $(0.93-1.47 \%)$, borneol $(1.07-4.67 \%)$, then sesquiterpenes: trans (E)-caryophyllene $(1.72-5.33 \%), \alpha$-humulene $(2.89-7.99 \%)$, viridiflorol $(4.27-7.99 \%)$, and the diterpene manool $(2.13-3.79 \%)$.

Thus, our results for the essential oil composition of sage complied with the reference values specified in the DAC 86 monograph for Salvia essential oil.
\end{abstract}

Key words: Salvia officinalis, essential oil composition, GC/FID/MS, R. Macedonia.

\section{Introduction}

Most of the species from genus Salvia have medicinal and horticultural importance as they produce many useful natural constituents including terpenes and flavonoids (Kelen and Tepe, 2008). They are counted as one of the largest members of the Lamiaceae family that includes around 900 species and has an almost cosmopolitan distribution (Mediterranean, Asia Minor, Central Europe and America etc).

"Sage", the dialect name of the genus Salvia is attributed to different species that are widely used in the food, drug and fragrance industry. The high diversity in secondary metabolites (essential oils and the phenolic derivatives) isolated from sage plants, possess excellent antimicrobial

\footnotetext{
* ivanacvetkovikj@gmail.com; ivanacvetkovic@yahoo.com
}

activity as well as antioxidant capacity and some are used as anticancer agents or have hypoglycemic effect (Kintzios, 2000; Miladinovic and Miladinovic, 2000; Khalil and Li, 2011). Of the many existing Salvia species, Salvia officinalis also known as "Dalmatian sage" or "Garden sage", has economic importance and can be used for preparation of various extracts and herbal remedies with antiseptic and antibacterial properties which are attributed to the rich chemical content of the essential oil and proven by the modern medical science (Velickovic et.al., 2003; Avato et.al., 2005; Delamare et.al., 2005; Bernotiene et.al., 2007). Although sage is an ancient spice and remedy, its importance today is quite limited to the Mediterranean countries (starting from Italy till Greece) (Mockute et.al., 2003; Hager, 2006). Some of the Salvia species, including S. officinalis (S. officinalis folium) and S. triloba (S. triloba folium) can be found in many pharmacopeias (Flamini et.al, 2005; Eur.Ph.7.0, 2010). Pharmacopoeias monographs of S. officinalis essential oil (Salviae aetheroleum - Helv VII; 
Salviae officinalis aetheroleum - DAC 86) are available, as well. The essential oil can be obtained by steam distillation of the leaves of S. officinalis (Helv VII), or from aboveground parts of the sage thus obtaining essential oil rich in thujone (DAC 86).

The well studied Dalmatian sage oil show differences in the total oil yield varying from 1.20 to $3.60 \%$ (with maximum in July) and gives characteristic sequence of the major constituents: $\alpha+\beta$-thujone $>$ camphor $>$ cineole. The principal components in the sage essential oil are the volatile monoterpenes, present in the following average distribution: 8.4 to $24.0 \%$ camphor, cineol (8.4 to $24.0 \%$ ), $\alpha$-thujone from 22.2 to $36.8 \%$, $\beta$-thujone from 4.0 to $27.5 \%$, borneol $(2.1 \%)$, bornyl acetate $(1.6 \%)$, camphene $(4.4 \%)$, $\beta$-caryophyllene (3\%), $\alpha$-humulene $(4.4 \%), \alpha$-pinene (3.5\%), $\beta$-pinene $(2.2 \%)$ and viridiflorol $(6 \%)$. The content and composition of the oil is subjected to periodic daily variations and fluctuations as well as to other ecological factors (climatic and soil conditions) (Hager, 2006). The relative amounts of major constituents in the sage essential oil are regulated with the German Drug Codex and the ISO 9909 standard (Table 3).

The Macedonian flora includes 37 species of genus Salvia. Up to present there are no evident data about essential oil composition of $S$. officinalis populations growing in Republic of Macedonia. The importance of S. officinalis drew our attention to examine and identify the active ingredients of the essential oils obtained by hydrodistillation of sage leaves collected from R. Macedonia.

\section{Materials and methods}

\section{Plant material}

The plant material from three different populations was harvest from Galicica Mtn., Jablanica Mtn., and Karaorman Mtn., located in the western part of Macedonia, nearby the Albanian border, during June year 2009 and 2010. The leaves were air dried and stored in a cool and dark place until distillation. The herb was authenticated as Salvia officinalis L. (Lamiacecae) by Dr. Gjoshe Stefkov, and voucher specimens (No. So-MKD 13/10; So-MKD 14/10; So-MKD 15/10) were deposited at the Herbarium at the Department of Pharmaceutical Botany, Institute of Pharmacognosy, Faculty of Pharmacy, Skopje, Macedonia.

\section{Essential oil isolation}

Essential oil isolation from sage leaves was performed by hydrodistillation in all-glass Clevenger apparatus following the procedure from European Pharmacopeia ( $\mathrm{Ph}$. Eur.7.0, 2010).

\section{Analysis of essential oils' chemical composition}

Each sample of essential oil was dissolved in xylene $(1: 1000 \mathrm{v} / \mathrm{v})$ and further analyzed on Agilent 7890A Gas
Chromatography system equipped with FID detector and Agilent $5975 \mathrm{C}$ mass spectrometer. HP-5ms 5\% phenyl 95\% dimethylpolysiloxane bonded phase capillary column (30 m x $0.25 \mathrm{~mm}$, film thickness $0.25 \mu \mathrm{m}$ ) was used. Analytical conditions were: oven temperature at $60{ }^{\circ} \mathrm{C}$ for $5 \mathrm{~min}$, then increased to $80{ }^{\circ} \mathrm{C}$ at rate of $1{ }^{\circ} \mathrm{C} / \mathrm{min}$ and held $2 \mathrm{~min}$ and at the end increased to $280^{\circ} \mathrm{C}$ at rate of $5^{\circ} \mathrm{C} / \mathrm{min}$ and held $5 \mathrm{~min}$; helium as carrier gas at a flow rate of $1 \mathrm{ml} /$ min; temperature of the injector $260^{\circ} \mathrm{C}$ and that of the FID detector $270{ }^{\circ} \mathrm{C}$; the GC split ratio $1: 1.1 \mu$ of each sample was injected per GC run. The mass spectrometry conditions were: ionization voltage $70 \mathrm{eV}$, ion source temperature 230 ${ }^{\circ} \mathrm{C}$, transfer line temperature $280{ }^{\circ} \mathrm{C}$ and mass range from 50 - 500 Da. The MS was operated in scan mode.

The compounds were identified on the basis of literature and estimated Kovat's (retention) indices that were determined using mixture of homologous series of normal alkanes $\left(\mathrm{C}_{9}-\mathrm{C}_{25}\right)$ analyzed under Automated Mass Spectral Deconvolution and Identification System (AMDIS)' conditions. Confirmation was done by comparing the mass spectra obtained from AMDIS with the reference spectra from Nist, Wiley and Adams mass spectra libraries.

Quantification of the essential oils components was performed using the normalization method of the GC/FID peak areas.

\section{Results and discussion}

The essential oil yields, obtained with hydrodistillation of the upper leaves from each sage population from Macedonia were as followed: So-MKD 13/10 $=1.8 \%$, SoMKD $14 / 10=1.4 \%$ and So-MKD $15 / 10=3.46 \%$. The amount of oils from Galicica and Jablanica populations (1.8\% and $1.4 \%$, respectively) were in accordance with literature references 1-2.5\% (ESCOP Monographs) or 1-3\% (Eur.Ph.7), while the isolate from Karaorman Mtn. (essential oil, 3.46\%) was above these values, and close to the upper limit for the Dalmatian essential oil.

By the means of GC-MS, total of sixty nine components, in all three samples of $S$. officinalis were identified and presented in Table 1.

The GC-MS analysis revealed sixty three components (37 monoterpenes, 17 sesquiterpenes, 5 diterpenes and 4 other components) in the essential oil from Galicica sage population, fifty seven (34 monoterpenes, 12 sesquiterpenes, 5 diterpenes and 6 other constituents) from Jablanica sage population and fifty one from Karaorman sage population (27 monoterpenes, 13 sesquiterpenes, 5 diterpenes and 6 other components - aromatic and aliphatic hydrocarbons, esters and etc). The quantities of the constitutive chemical groups of the essential oils of Salvia officinalis populations are shown in Fig. 1.

The most abundant constituents, in all three samples, were the terpene hydrocarbons, encompassing the volatile monoterpenes: camphor $(13.15-25.91 \%), \alpha$-thujone (19.25 - 26.33\%), $\beta$-thujone (2.03 - 5.28\%), 1,8-cineole 
Table 1. Chemical composition of essential oils isolated from three different populations of $S$. officinalis from R. Macedonia

\begin{tabular}{|c|c|c|c|c|c|c|}
\hline No. & KIL & KIE & Component & $\begin{array}{c}\begin{array}{c}\text { So-MKD } 13 / 10 \% \\
(\mathrm{~m} / \mathrm{m})\end{array} \\
\end{array}$ & $\begin{array}{c}\text { So-MKD 14/10 } \\
\%(\mathrm{~m} / \mathrm{m})\end{array}$ & $\begin{array}{c}\text { So-MKD 15/10 } \\
\%(\mathrm{~m} / \mathrm{m})\end{array}$ \\
\hline 1 & / & 921.0 & 4-heptanol & I & 0.26 & 0.42 \\
\hline 2 & 926 & 924.7 & tricyclene & I & 0.08 & 0.08 \\
\hline 3 & 931 & 927.9 & alpha-thujene & 0.05 & / & / \\
\hline 4 & 939 & 935.8 & alpha-pinene & 1.20 & 0.93 & 1.47 \\
\hline 5 & 953 & 951.2 & camphene & 2.91 & 1.94 & 1.96 \\
\hline 6 & 978 & 976.7 & 1-octen-3-ol & 0.07 & 0.07 & 0.05 \\
\hline 7 & 980 & 980.0 & beta-pinene & 0.78 & 0.22 & 0.46 \\
\hline 8 & 991 & 991.2 & myrcene & 0.80 & 0.50 & 0.81 \\
\hline 9 & 994 & 969.1 & mesitylene & 0.09 & 0.06 & 0.10 \\
\hline 10 & 1000 & 999.9 & n-decane & 0.05 & 0.04 & 0.06 \\
\hline 11 & 1005 & 1007.1 & alpha-phellandrene & 0.09 & 0.06 & 0.03 \\
\hline 12 & 1018 & 1018.6 & alpha-terpinene & 0.16 & 0.15 & 0.10 \\
\hline 13 & 1026 & 1026.1 & p-cymene & 0.28 & 0.41 & 0.79 \\
\hline 14 & 1031 & 1030.4 & limonene & 2.15 & 1.84 & 1.63 \\
\hline 15 & 1033 & 1033.5 & 1,8-cineole & 6.51 & 9.92 & 13.60 \\
\hline 16 & 1062 & 1059.8 & gamma-terpinene & 0.29 & 0.19 & 0.54 \\
\hline 17 & 1065 & 1069.0 & cis-sabinene hydrate & 0.05 & 1 & / \\
\hline 18 & 1088 & 1090.6 & terpinolene & 0.51 & 0.26 & 0.26 \\
\hline 19 & 1098 & 1101.3 & linalool & 0.60 & 0.40 & 0.30 \\
\hline 20 & 1110 & 1110.4 & cis-thujone & 19.98 & 19.25 & 26.33 \\
\hline 21 & 1111 & 1119.4 & trans-thujone & 2.03 & 3.26 & 5.28 \\
\hline 22 & 1125 & 1128.6 & alpha-campholenal & 0.06 & 0.03 & 0.03 \\
\hline 23 & 1133 & 1136.9 & iso-3-thujanol & 0.07 & 0.06 & / \\
\hline 24 & 1139 & 1143.7 & trans-sabinol & 0.10 & 0.07 & 0.10 \\
\hline 25 & 1143 & 1150.1 & camphor & 25.91 & 23.79 & 13.15 \\
\hline 26 & 1156 & 1160.0 & isoborneol & 0.07 & 0.06 & 1 \\
\hline 27 & 1160 & 1163.9 & trans-pinocamphone & 1 & 0.06 & 0.16 \\
\hline 28 & 1165 & 1168.9 & borneol & 4.26 & 4.67 & 1.07 \\
\hline 29 & 1177 & 1179.3 & terpinen-4-ol & 0.39 & 0.43 & 0.44 \\
\hline 30 & 1183 & 1186.3 & p-cymene-8-ol & 0.06 & 0.09 & 0.04 \\
\hline 31 & 1189 & 1192.6 & alpha-terpineol & 0.20 & 0.17 & 0.11 \\
\hline 32 & 1194 & 1199.2 & myrtenol & 0.04 & 0.26 & 0.26 \\
\hline 33 & 1217 & 1220.1 & trans-carveol & 0.07 & 0.17 & 0.04 \\
\hline 34 & 1226 & 1225.0 & cis-carveol & 0.03 & I & I \\
\hline 35 & 1233 & 1230.0 & isobornyl formate & 0.03 & 0.05 & / \\
\hline 36 & 1235 & 1237.2 & neral & 0.02 & 0.04 & l \\
\hline 37 & 1237 & 1241.6 & pulegone & 0.03 & 1 & l \\
\hline 38 & 1255 & 1254.0 & geraniol & 0.02 & / & l \\
\hline 39 & 1267 & 1269.0 & iso-3-thujanol acetate & 0.03 & / & l \\
\hline 40 & 1273 & 1276.0 & neo-3-thujanol acetate & 0.06 & 0.08 & l \\
\hline 41 & 1285 & 1288.4 & bornyl acetate & 3.86 & 3.53 & 0.43 \\
\hline 42 & 1290 & 1293.8 & trans-sabinyl acetate & 0.31 & 0.33 & 0.16 \\
\hline 43 & 1298 & 1301.2 & carvacrol & 0.05 & 0.12 & 0.10 \\
\hline 44 & / & 1327.5 & myrtenyl acetate & l & & 0.05 \\
\hline 45 & 1337 & 1338.4 & trans-carvyl acetate & 0.03 & 0.07 & l \\
\hline 46 & 1342 & 1344.2 & piperitenone & / & 0.06 & l \\
\hline 47 & / & 1381.7 & 6,9-guaiadiene & 0.11 & / & l \\
\hline 48 & 1386 & 1390.4 & alpha-isocomene & 0.18 & / & 0.14 \\
\hline
\end{tabular}

Макед. фарм. билт., 57 (1, 2) 71 - 76 (2011) 


\begin{tabular}{|c|c|c|c|c|c|c|}
\hline No. & KIL & KIE & Component & $\begin{array}{c}\text { So-MKD 13/10\% } \\
(\mathrm{m} / \mathrm{m})\end{array}$ & $\begin{array}{c}\text { So-MKD 14/10 } \\
\%(\mathrm{~m} / \mathrm{m})\end{array}$ & $\begin{array}{c}\text { So-MKD 15/10 } \\
\%(\mathrm{~m} / \mathrm{m})\end{array}$ \\
\hline 49 & 1409 & 1418.6 & alpha-gurjunene & 0.05 & / & / \\
\hline 50 & 1418 & 1424.2 & (E)-caryophyllene & 1.716 & 4.21 & 5.33 \\
\hline 51 & 1 & 1454.8 & trans-cadina-1(6),4 -diene & 1.69 & 1.32 & / \\
\hline 52 & 1453 & 1458.5 & alpha-humulene & 2.89 & 5.21 & 7.34 \\
\hline 53 & 1467 & 1465.5 & 9-epi-(E)-carryophyllene & 0.33 & 0.44 & 0.34 \\
\hline 54 & 1478 & 1479.0 & gamma-muurolene & 0.44 & / & / \\
\hline 55 & 1493 & 1499.5 & viridiflorene & 2.67 & 2.77 & 2.04 \\
\hline 56 & 1528 & 1510.9 & zonarene & 0.07 & 0.07 & 0.04 \\
\hline 57 & 1524 & 1527.1 & delta-cadinene & 0.15 & 0.09 & 0.04 \\
\hline 58 & 1581 & 1588.2 & caryophyllene oxide & 0.25 & 0.40 & 0.35 \\
\hline 59 & 1590 & 1597.3 & viridiflorol & 4.27 & / & 7.99 \\
\hline 60 & 1593 & 1600.0 & humulene epoxide I & 0.16 & l & / \\
\hline 61 & 1606 & 1614.4 & humulene epoxide II & 0.49 & 0.75 & 0.81 \\
\hline 62 & 1630 & 1637.0 & muurola-4,10(14)-dien-1-b-ol & 0.45 & 1.21 & 1.19 \\
\hline 63 & 1664 & 1674.8 & 14-hydroxy-(Z)-caryophyllene & 0.17 & 0.77 & 0.46 \\
\hline 64 & / & 1810.2 & alpha-bisabolene & 1 & 0.16 & 0.11 \\
\hline 65 & 1894 & 1901.8 & rimuene & 0.08 & 0.08 & 0.05 \\
\hline 66 & 1950 & 1917.4 & $\begin{array}{l}\text { isopimara-9(11)-15-dien } \\
\text { sandaracopimara- } 8(14) \text {, }\end{array}$ & 0.19 & 0.21 & 0.16 \\
\hline 67 & 1960 & 1668.8 & 15 -diene & 0.25 & 0.21 & 0.13 \\
\hline 68 & l & 1977.7 & labd-7,13-dien-15-ol & 0.11 & 0.09 & 0.06 \\
\hline \multirow[t]{2}{*}{69} & 2056 & 2061.2 & manool & 2.13 & 3.79 & 3.06 \\
\hline & & & Total: & 93.13 & 95.73 & 100.00 \\
\hline
\end{tabular}

*No. - Ordinal number according to the elution order of the components; KIL - Kovat's Index Literature; KIE - Kovat's Index Estimated, So-MKD 13/10 - Salvia officinalis population from Galicica Mtn.; So-MKD 14/10 - Salvia officinalis population from Jablanica Mtn.; So-MKD 15/10 - Salvia officinalis population from Karaorman Mtn.

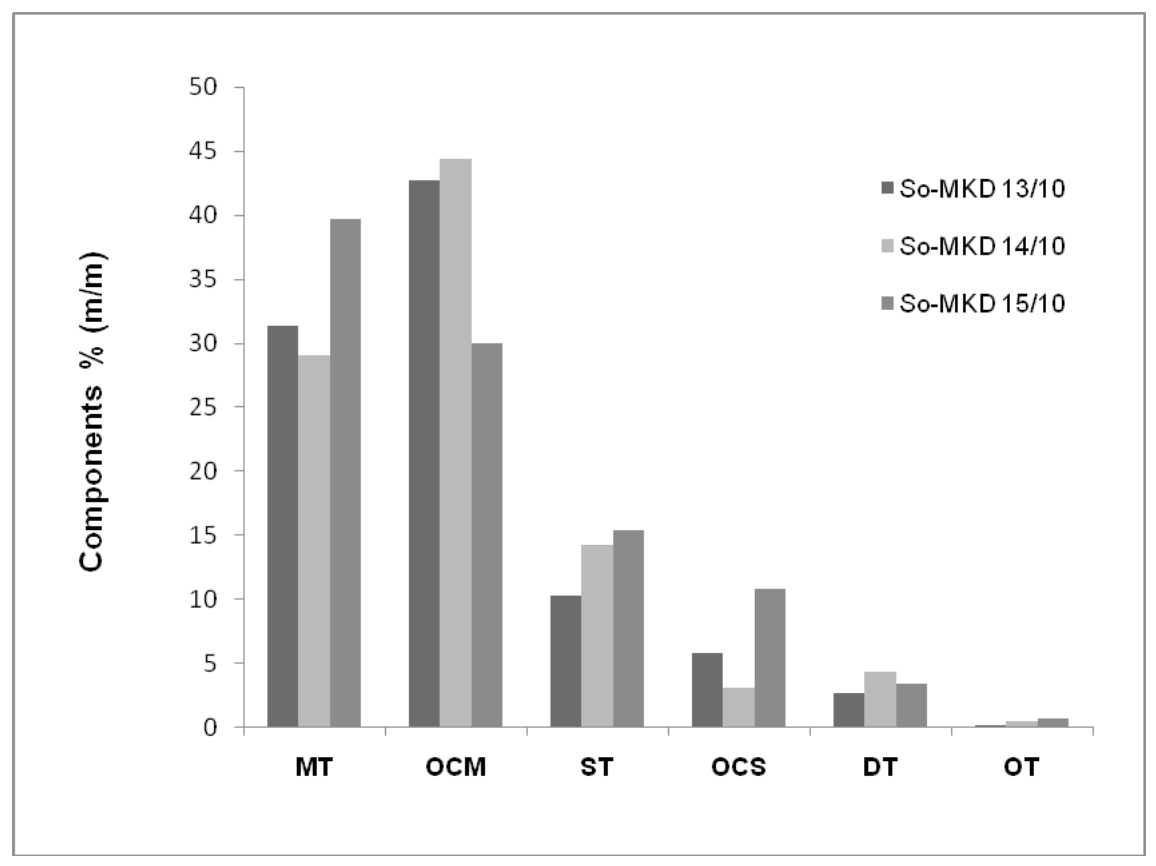

Fig. 1. Presentation of different classes of terpenes and their abundance in the essential oils of Macedonian sage plants *MT - monoterpene; OCM - oxygen containing monoterpene; ST - sequiterpene; OCS - oxygen containing sesquterpene; DT - diterpene; OT - other type (aliphatic and aromatic hydrocarbons, aromatic esters etc.); So-MKD 13/10 - Salvia officinalis population from Galicica Mtn.; SoMKD 14/10 - Salvia officinalis population from Jablanica Mtn.; So-MKD 15/10 - Salvia officinalis population from Karaorman Mtn. 
$(6.51-13.60 \%), \alpha$-pinene $(0.93-1.47 \%)$, borneol $(1.07-$ $4.67 \%)$, the sesquiterpenes: trans $(\mathrm{E})$-caryophyllene $(1.72$ $-5.33 \%), \alpha$-humulene $(2.89-7.99 \%)$, viridiflorol $(4.27$ $7.99 \%)$, and the diterpene manool $(2.13-3.79 \%)$.

Our results for the essential oil composition of sage, thus, comply with the reference values specified in the German Drug Codex monograph for Salvia officinalis essential oil. The composition analysis of the volatile constituents of the three Macedonian sage populations showed that only the essential oil from Karaorman Mtn. population belongs to the thujone-rich oils, while essential oils isolated from Galicica Mtn. and Jablanica Mtn. populations had camphor as major component. Typically, according to some authors (Perry et.al., 1999; Walch et.al., 2011), three are three Dalmatian Sage chemotypes with low (9\%), medium (22-28\%), and high (39-44\%) thujone contents. Concerning the latter, essential oils from $S$. officinalis samples from Galicica Mtn. and Jablanica Mtn. populations, belong to the Sage group containing medium thujone amounts and cannot meet with the requirements for the sage essential oil chemical composition reported in other available scientific literature where the demand of thujone content is stated as 35-60\% (e.g. Radulescu et.al., 2004; Maksimovic et.al., 2007). Due to the camphor predominance in essential oil isolated from Galicica Mtn. population, this essential oil cannot meet the ISO 9909 standard (Table 2).

This inter-specific comparison of the essential oils isolated from three Salvia officinalis populations from Macedonia showed differences in the amount of the principle components especially in the oils obtained from Galicica and Jablanica populations what emphasize the role of the environmental factors (light, soil, water, time of harvest, drying, etc.) on the yield and chemical composition of the essential oil even when they are from same region.

\section{Conclusion}

The essential oils' yields obtained after hydrodestilation of leaves from three different populations of sage from Macedonia varied from 1.40 to $3.46 \%$. The essential oil composition of all three sage populations complies with the reference values specified in the DAC 86 monograph for Salvia essential oil. Yet, the requirements of the ISO 9909 standard have not been met. Nevertheless, the set of components identified in the three samples of the Macedonian sage oil match up with the essential oil composition of the Dalmatian sage, though the set differs in relative content of the principle components.

\section{References}

Avato, P., Fortunato, I.M., Ruta, C., D’Elia, R., 2005. Grandular hairs and essential oils in micropropagated plants of Salvia officinalis L. Plant Science 169, 29-36.

Bernotiene, G., Nivinskiene, O., Butkiene, R., Mockute, D., 2007. Essential oil composition variability in sage (Salvia officinalis L.). Chemija 18 (4), 38-43.

DAC 86 - Deutsher Arzneimittel Codex (German Drug Formulary) 86.

Delamare, L.A.P., Moschen-Pistorello, I.T., Artico L., AttiSerafini, L., Echeverrigaray, S., 2005. Antibacterial activity of the essential oils of Salvia officinalis L. and Salvia triloba L. cultivated in South Brazil. Food Chemistry 100 (2), 603608 .

Table 2. Comparison of the dominant constituents of the essential oils obtained after hydrodestilation of the three Salvia officinalis populations from R. Macedonia with referent literature

\begin{tabular}{|c|c|c|c|c|c|c|c|c|}
\hline $\begin{array}{c}\text { Constituents } \\
\%(\mathrm{~m} / \mathrm{m})\end{array}$ & $\begin{array}{c}\text { So-MKD } \\
13 / 10 \\
\end{array}$ & $\begin{array}{c}\text { So-MKD } \\
14 / 10 \\
\end{array}$ & $\begin{array}{c}\text { So-MKD } \\
15 / 10 \\
\end{array}$ & DAC $86^{1}$ & ISO $9909^{2}$ & Serbia $^{3}$ & Romania $^{4}$ & Croatia $^{5}$ \\
\hline 1,8-cineole & 6.51 & 9.92 & 13.61 & $6.00-16.00$ & $5.50-13.00$ & 9.79 & 6.72 & 0.90 \\
\hline cis-thujone & 19.98 & 19.25 & 26.33 & $>20.00$ & $18.00-43.00$ & 24.88 & 21.85 & 57.00 \\
\hline trans-thujone & 2.03 & 3.26 & 5.28 & & $3.00-8.50$ & l & 5.51 & 15.00 \\
\hline camphor & 25.91 & 23.79 & 13.15 & $14.00-37.00$ & $4.50-24.50$ & 16.03 & 11.25 & 3.30 \\
\hline borneol & 4.26 & 4.67 & 1.07 & $\leq 5.00$ & l & l & 2.58 & I \\
\hline bornyl acetate & 3.86 & 3.53 & 0.43 & $\leq 5.00$ & $<2.50$ & l & 3.22 & l \\
\hline$\alpha$-pinene & 1.20 & 0.93 & 1.47 & l & $1.00-6.50$ & l & l & / \\
\hline$\alpha$-humulene & 2.89 & 5.21 & 7.34 & I & $0-12.00$ & I & 4.51 & / \\
\hline camphene & 2.91 & 1.94 & 1.96 & 1 & $1.50-7.00$ & 1 & 1.66 & l \\
\hline limonene & 2.15 & 1.84 & 1.63 & l & $0.50-3.00$ & l & l & l \\
\hline viridiflorol & 4.27 & l & 7.99 & l & I & l & 11.71 & 14.20 \\
\hline manool & 2.13 & 3.79 & 3.06 & 1 & 1 & 1 & 9.15 & 1 \\
\hline
\end{tabular}

${ }^{1}$ Monograph for Salvia officinalis essential oil in DAC 86 (German Drug Formulary 86); ${ }^{2}$ ISO 9909 standard for medicinal uses regulates the amounts of nine constituents in the sage essential oil, Ref: Mockute et.al., 2003; Bernotiene et.al., 2007; ${ }^{3}$ Salvia officinalis essential oil from Serbia, Ref.: Miladinovic and Miladinovic, 2000; ${ }^{4}$ Salvia officinalis essential oil from Romania, Ref.: Radulescu et.al., 2004; ${ }^{5}$ Salvia officinalis essential oil from Croatia, Ref.: Maksimovic et.al., 2007; So-MKD 13/10 - Salvia officinalis population from Galicica Mtn.; So-MKD 14/10 - Salvia officinalis population from Jablanica Mtn.; So-MKD 15/10 - Salvia officinalis population from Karaorman Mtn. 
European Pharmacopoeia 7.0, 2010.

ESCOP, 2003. Salviae officinalis folium (Sage leaf). ESCOP Monographs ( $2^{\text {nd }}$ ed $), 452-455$.

Flamini, G., Cioni, P.L., Morelli, I., Bader, A., 2007. Essential oils of the aerial parts of three Salvia species from Jordan: Salvia lanigera, S. spinosa and S. syriaca. Food Chemistry $100,732-735$

Hager, 2004. Salvia. HagerROM 2004, Springer, Heidelberg.

Kelen, M., Tepe, B., 2008. Chemical composition, antioxidant and antimicrobial properties of the essential oils of three Salvia species from Turkish flora. Bioresource Technology 99 (10), 4096-4104.

Khalil, R. and Zheng-Guo, L., 2011. Antimicrobial activity of essential oil of Salvia officinalis L. collected in Syria. African Journal of Biotechnology 10 (42), 8397-8402.

Kintzios, S.E., 2000. Sage: the genus Salvia, Harwood academic publisher, Australia, Canada.

Maksimovic, M., Vidic, D., Milosh, M., Sholic, M.E., Abadzic, S., Siljak-Yakovlev, S., 2007. Effect of the environmental conditions on essential oil profile in two Dinaric Salvia species: $S$. brachyodon Vandas and $S$. officinalis $\mathrm{L}$. Biochemical systematic and ecology 35, 473-478.

Miladinovic, D., Miladinovic, Lj., 2000. Antimicrobial activity of essential oil of sage from Serbia. Facta Universitatis, Series: Physics, Chemistry and Technology 2 (2), 97-100.
Mockute, D., Nivinskiene, O., Bernotiene, G., Butkiene, R., 2003. The cis-thujone chemotype of Salvia officinalis L. essential oils. Chemija 14, 216-220.

Perry, N.B., Anderson, R.E., Brennan, N.J., Douglas, M.H., Heaney, A.J., McGimpsey, J.A., Smallfield, B.M., 1999. Essential oils from dalmatian sage (Salvia officinalis L.): variations among individuals, plant parts, seasons, and sites. Journal of Agricultural Food Chemistry 47 (5), 204854.

Radulescu, V., Chiliment, S., Oprea, El., 2004. Capillary gas chromatography-mass spectrometry of volatile and semi-volatile compounds of Salvia officinalis. Journal of Chromatography A 1027, 121-126.

Velickovic, A.S, Ristic, M.S., Velickovic, D.T., Ilic, S.N., Mitic, N.D., 2003. The possibilities of the application of some species of sage (Salvia L.) as auxiliaries in the treatment of some diseases. Journal of Serbian Chemical Society 68 (6), 435-445.

Walch, S.G., Kuballa, T., Stuhlinger, W., Lachenmeier, D.W., 2011. Determination of the biologically active flavour substances thujone and camphor in foods and medicines containing sage (Salvia officinalis L.). Chemistry Central Journal 5 (44).

\title{
Резиме
}

\section{Состав на етерично масло од диво растечки жалфии од Р. Македонија}

\author{
Ѓоше Стефков, Ивана Цветковиќ*, Марија Карапанџова, Светлана Кулеванова
}

\author{
Институт за Фармакогнозија, Фармацевтски факултет, Универзитет “Св. Кирил и Методиј”, Скопје, Р. \\ Македонија
}

Клучни зборови: Salvia officinalis, состав на етерично масло, GC/FID/MS, Р. Македонија.

Главна цел на студијата беше анализа и идентификација на составните компоненти на етеричното масло изолирано од популациите на S. officinalis кои растат во Република Македонија и нивна споредба со далматинска жалфија. Приносот на етерично масло добиено со хидродестилација на листовите од трите различни популации на Salvia officinalis L. од Република Македонија се движи од 1.46 до 3.46\%. Co GC/FID/MS анализата на етеричните масла идентификувани се 63, 57 и 51 компонента кај популациите од Галичица, Јабланица и Караорман, соодветно. Како главни компоненти на маслата во сите три примероци се терпенските јаглеводороди, вклучувајќи ги монотерпените: камфор (13.15 - 25.91\%), $\alpha$-тујон (19.25 - 26.33\%), $\beta$-тујон (2.03 - 5.28\%), 1,8цинеол $(6.51-13.60 \%), \alpha$-пинен $(0.93-1.47 \%)$, борнеол $(1.07-4.67 \%)$, по што следат сескитерпените: транс (Е)-кариофилен $(1.72-5.33 \%), \alpha$-хумулен $(2.89-7.99 \%)$, виридифлорол $(4.27-7.99 \%)$ и дитерпенот манол $(2.13-3.79 \%)$. Следствено, составот на етеричното масло од испитуваните жалфии од Р. Македонија одговара на референтните вредности утврдени во монографијата за етерично масло на жалфија во Германскиот кодекс за лекови (DAC 86). 